\title{
Country branding comparison between Slovak Republic and United Kingdom in Future Brand Country Index
}

\author{
Iveta Kufelová ${ }^{1, *}$ and Monika Raková $^{2,}$ \\ ${ }^{1}$ University of Economics in Bratislava, Faculty of Business Management, Department of Business \\ Economy, Dolnozemská cesta1, 85235 Bratislava, Slovak republic \\ ${ }^{2}$ University of Economics in Bratislava, Faculty of Business Management, Department of Business \\ Economy, Dolnozemská cesta1, 85235 Bratislava, Slovak republic
}

\begin{abstract}
Nowadays are known many indexes, which are rating specific countries by their performance in chosen areas. This work will be concentrated on the brands of countries valuated by brand indexes. For purposes of job we have chosen the Future Brand Country Index in order to achieve the most objective result of comparison between Slovak Republic and Great Britain. Although they are known certain number of indexes, factors used in Future Brand Country Index are considered by us as the best suitable for this work. This index valuates strength of perception of the country brand across certain dimensions, which are Value System, Quality of Life, Business Potential, Heritage and Culture, Tourism and Made in. These dimensions consist of numerous associations with specific country which will be specified later. Purpose of our work is to analyse results of Slovak republic and Great Britain, their position in Future Brand Index in 2014 and in 2019 and find reasons of their improvement or deterioration. Since Future Brand Index does not publish data and analyses of these countries, our work will be concentrated on analysing key dimensions of index which could affect position of chosen countries in Future Brand index.
\end{abstract}

\section{Introduction}

Nation branding should be interpreted as the practice of building and communicating the country image to the rest of the world, through diplomacy, trading, export and tourism. First mention of this term was in 1996 by the British brand practitioner Simon Anholt [15]. In accordance Miazhevich, nation branding means presenting a country as a brand or a product to an external audience through forms of strategic communication [17]. By the author, Branding includes the visual, verbal, textual and behavioralpresentations and expressions of an organization's identity as well as decisions and strategies underpinning such expressions [19]. Many researchers explore a region where nation branding has rapidly proliferated: Central and East European countries, faced with the need to (re)formulate themselvesand

* Corresponding author: iveta.kufelova@euba.sk 
gain global visibility as nations after the collapse of communist regimes, while alsoundergoing economic and political transition and coming to terms with a traumaticpast. These factors caused'a state of inadequacy'affecting both individual psychologiesand political decisions [16]. The two predominant approaches in place branding research are tourism based that focus on branding the country as a tourism destination and product based, that focus on associating countries with products [18]. The perception of visitors is a key element in building the country's image, and should become a new perspective in the study of nation branding states that the image of a country directly affects the behavior of foreign clients: the final consumers and investors. A country image is a set of connotations that take shape in the minds of people based on what they hear, say and remember about a specific destination. [20]

\section{Methodology and data}

As we have already mentioned above, this index consists of 6 dimensions which include numerous associations stated in the Table 1.

Table 1. Own elaboration of Future Brand Index dimensions with connected associations

\section{VALUE SYSTEM}

QUALITY OF LIFE

\section{BUSINESS POTENTIAL}

HERITAGE AND CULTURE

TOURISM
1. Political Freedom

2. Environmental standards

3. Tolerance

1. Health and Education

2. Standard of Living

3. Safety and Security

4. Would like to live/study there

1. Good for Business

2. Advanced Technology

3. Good Infrastructure

1. Historical Points of Interest

2. Heritage, Art and Culture

3. Natural Beauty

1. Value for money

2. Range of Attractions

3. Resort and lodging options

4. Would like to visit for vacation

5. Food

1. Make products that are authentic

2. Make products of high quality

3. They create unique products

4. Would like to buy products made in that country

Table 1. Own elaboration of Future Brand Index dimensions with connected associations base on https://www.futurebrand.com/uploads/Country-Brand-Index-2015-15.pdf 
With respect to the limited space, we have chosen just specific associations considered as the most suitable for index results of chosen countries. Both versions of indexes, also from 2014 and from 2019, use the same methodology and valuation of the countries. Difference of versions are their objectives for specific years, which are not considered in our work due to respect to no relevance for overall ranking and limited space. In 2014 was Slovak republic on $44^{\text {th }}$ place from 118 countries but in 2019 was position of Slovak republic better and end up on $35^{\text {th }}$ place. Our second country of interest is Great Britain, which was in 2014 on $12^{\text {th }}$ place but in 2019 fell down on $19^{\text {th }}$ place. [1]

\subsection{Value System}

Now we will analyse reasons why their position dropped or rised and we will start with the first Value System dimension, where we chose environmental standards. For this association we used data of ecological footprint for stated countries and their change through years 2013-2016. This footprint is measured as a biocapacity reserve or deficit. According to Global Footprint Network, it is approximately 12,2 billion hectares of the land, which can be productively used and that means, it is 1,6 hectare of productive land per person. If country will exceed this land per person, country has ecological deficit and that means, that country uses more land than can planet effectively recover and if uses less, it has ecological reserve. In 2014 had a Great Britain biocapacity deficit $-3,5$ global hectares. Main reason of this deficit was the production of CO2 by Great Britain, which was in 2014195160525.31 metric tons. In 2016 Great Britain showed small improvement and biocapacity deficit dropped on 3,3 global hectares. This drop could be affected by decrease of producing $\mathrm{CO} 2$ by more than 10 million tons. This deficit is considered as one of the highest in the world also with USA, Saudi Arabia, Italy and et cetera. As we can see on the Figure 1 Slovakia got better in these years but still had a biocapacity deficit. In 2014 the deficit was -1,4 global hectares and we can assume, that it was also caused by production of the CO2 in the amount of 13951632.83 metric tons.

\section{Biocapacity deficit of Slovak republic and Great Britain} 2013-2016

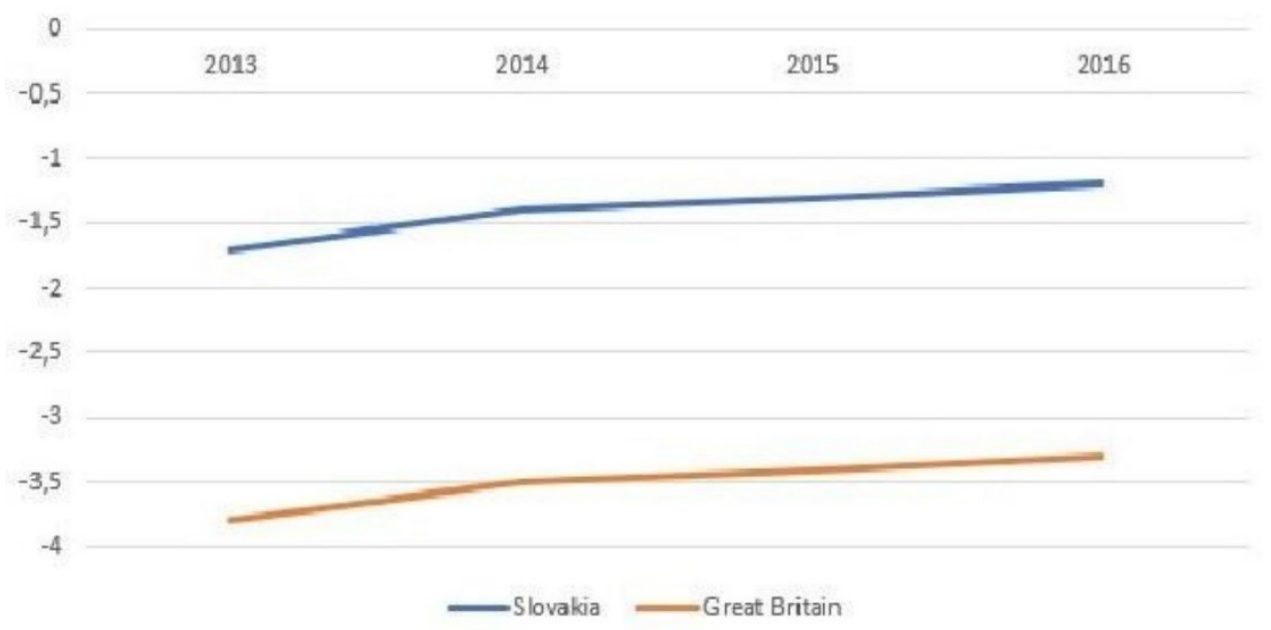

Fig. 1 Own elaboration of biocapacity deficit of Slovak republic and Great Britain 
In 2016 Slovak republic also indicated small improvement, when deficit fell on -1,2 global hectares. This result could be affected by decrease of the production of $\mathrm{CO} 2$ and decrease of cropland use. Reason, why were these countries decreasing their $\mathrm{CO} 2$ emissions was their participation in Kyoto protocol. [2][3]

\subsection{Quality of Life}

Second dimension is Quality of Life. The concept of social quality of life is used to analyze the degree of people's diverse needs satisfaction; they are spiritual, material and social needs. This category, being an interdisciplinary one, is an object of study of not only economy, but also philosophy, and sociology. [24] In the paper we specifically concentrate on safety and security. For purposes of this association we have used data from Global Peace Index. This index rates countries in order to their participation in conflicts, stability inside their country thus for example level of violent crime or violent demonstrations, but also their participation to world peace as a contribution to UN peacekeeping missions. This is one of the associations where Slovak republic had a better position than Great Britain. As we can see on the Figure 2, Slovak republic and Great Britain keep stable position in Global Peace Index with a difference, that Slovak republic has since 2014 till 2019 better results than Great Britain.

\section{Comparision of Slovak and Great Britains rank in Global Peace Index}



Fig. 2. Own elaboration of comparision of Slovak and Great Britain rank in Global Peace Index

The worst rank of the United Kingdom was reached in 2018, when from 163 countries United Kingdom end up on $57^{\text {th }}$ place. According to the Global Peace Index 2018 report, it was affected by,,relation to rising nationalism “. Slovak republic has the worst score in 2017 what could be affected by murder of the journalist and small percentage of change in acceptance of the rights of others. [4][5][6]

\subsection{Business Potential}

Next dimension is business potential, where we analyse association Good for Business. For this association we chose Doing Business Index for the rank chosen countries through the 
years 2014-2019. The Doing Business Index (DBI) is a multidimensional measurement of the aspects of business regulation, which affect domestic small and medium-size firms. It is developed by the World Bank who acknowledged the importance of ease of doing business for the economic development of countries. [23]

\section{Position of Slovak Republic and United Kingdom in Doing Business Index in 2014-2020}



Fig. 3. Own elaboration of comparison of Slovak republic and United Kingdom in 2014-2020

As we can see on the Figure 3, United Kingdom is since 2014 in the first ten countries where it is easiest doing business in. United Kingdom has achieved these results mainly thanks to the good score in topics of Starting a Business, Getting Electricity and Trading across Borders. The weakest parts of the score are in topics of Enforcing Contacts and Getting Credit. If we look on the case of Slovak republic, we can easily understand why United Kingdom has a better rank. If we want to compare business environment in United Britain and Slovak republic, we can compare for example Starting a Business. In Slovak republic it takes 21,5 day to get through bureaucracy to start a new business, whereas in United Kingdom 4,5 days. Getting electricity to company building can take in United Kingdom 46 days, whereas in Slovak republic almost twice more. Only one topic, where was Slovak republic better than United Kingdom was Trading across Borders, where Slovak republic has first place and full score. [7]

\subsection{Heritage and Culture}

Fourth dimension is Heritage and Culture. The working definition of cultural heritage is the definition of a set of resources that are protected, preserved or restored because they are worthy of transfer to new generations. These include monuments, including archaeological works, works of art, films, books or documents held by museums, libraries and archives, as well as intangible items such as skills, rituals and ceremonial events. [21] We analyse whole three associations, thus Historical Points of Interest, Heritage, Art and Culture, Natural Beauty with number of properties inscribed on the World Heritage List. We analyse these association this way because it is no index or a better way how to measure Culture and Heritage of the country. Slovak republic has 7 properties which are inscribed on the World Heritage List as Bardejov Town Conservation Reserve or Wooden Churches, whereas Great Britain has 32 properties as a Stonehenge, Town or London or Henderson Island. It is need to say, that it can be more reasons of these differences, for example diversion of Slovak and 
the Czech Republic in 1992, or the fact that Great Britain has almost 5 times bigger area than Slovak republic. [7] [8]

\subsection{Tourism}

Fifth dimension is tourism where we will analyse multiple associations. There is agreement in the scholarly literature on the tourism sector that it is difficult to define and specify the concept of tourism competitiveness due to the influence of multiple factors or dimensions that influence a destination's success. [22] For better understanding we compared number of tourists of both countries per year in Figure 4 below.

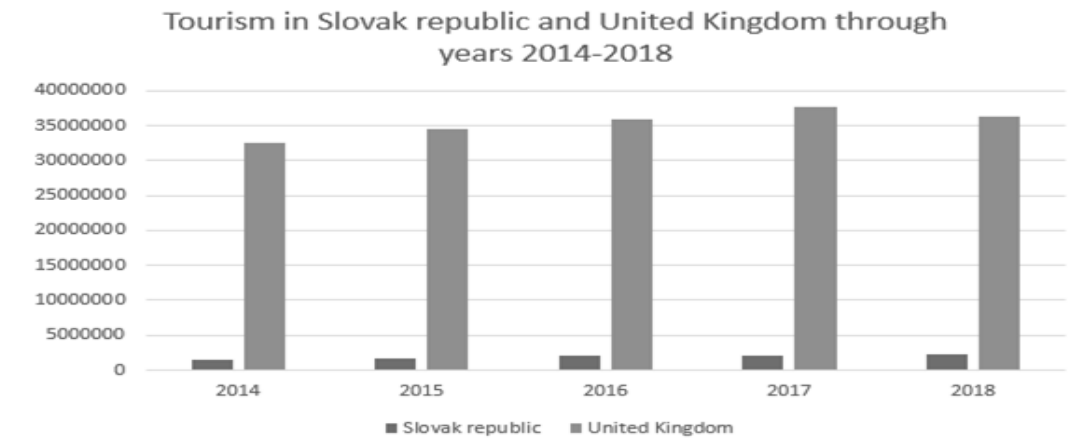

Fig. 4. Own elaboration of comparation of tourism in Slovak republic and United Kingdom

According to World Bank, in 2018 was Great Britain visited approximately by16 times more tourists than Slovakia. This fact is highly affected by smaller size of Slovak republic area, power of the economy and power of the country brand in the world. Tourism in Slovak republic is rising every year also thanks to project Good Idea Slovakia, which is represented in the homeland but mainly in abroad at political events but also on the business missions by SARIO agency. According to Travel in Slovakia, the most interesting regions to visit are Bratislava, Košice, Horehronie and Tatras and Northern Spiš. Slovak republics range of attractions thus include mostly visiting nature and countryside, cultural monuments and tourist life in bigger cities. Tourism in Slovak republic also includes beer tourism, which is type of tourism motivated by experiencing new tastes of beer flavours, types of technology of beer manufacture and getting familiar with history of beer and beer region. Second important type of tourism in Slovak republic is food tourism. Nowadays, it is more and more important to get countryside and its food tradition to attention of the tourist. This process can help to restore food tourism in Slovak republic. Slovak republic context of food tourism contains mainly from sheep's milk diary production, which is considered as a part of Slovak identity. Culinary tourism in this area should be supported also because of its long tradition in manufacturing these products, whereas first signs of coagulated milk leads to the prehistoric times 2000 years BC. If we will analyse case of the Great Britain, first we notice that as was mentioned, Great Britain is visited by tourist 16 times more than Slovakia. According to Statista, Great Britain is mostly visited to experience British big city life. This fact indicates number of overseas visits to the Great Britain in 2018, when 19090000 people visited London and Lothian, which is more known for wonderful nature, was visited 4 times less by 2433000 tourists. According to Visit Britain, the country has big range of attractions including seeing traditional British cultural monuments, for example Tower of London, Stonehenge or Pontcysyllte aqueduct and Canal which are also inscribed on the UNESCO World Heritage List. Tourist have opportunity to visit also royal part of the Great Britain by visiting official royal residences, royal events or parks. Food and drink tourism in the country 
can be for tourist interesting because of tradition of afternoon tea, which is in Great Britain famous for centuries. Tourists use to visit also British pubs and cocktail bars. Food tourism in Great Britain is highly affected by globalisation which brought food of whole world in there, but it is easy to experience also the traditional food tourism. United Kingdom has a long tradition to serve cornish pasties or famous fish and chips. [9] [10] [11]

\subsection{Made in}

In the last dimension, made in, we concentrate on the products from Slovakia and United Kingdom that are unique, high quality and authentic. We start with Slovak products, specifically with the mead. Mead is an alcoholic beverage which is manufactured by fermenting honey mixed with water and fruit. This beverage is for Slovak republic significant and has a manufacturing tradition, which leads to its high quality. Quality of the Slovak mead was approved by prestigious Mazer cup several times, where it was awarded as the best mead in world. Next unique product is Slovak Lyra Chocolate, which was awarded in multiple competitions as Great Taste, International Chocolate awards but also by World Packaging Organisation. It is difficult to compare Slovak republic and United Kingdom in the area of a manufacture. Whereas Slovak republic is producing lot of unique products mainly in the food industry, Great Britain has a bigger range of production. Of course, we can also mention British gin manufacturing tradition but we can see this association as in the wider range, since Great Britain is a country, which is the homeland for the famous, significant and luxury cars as a Rolls Royce or Jaguar. This fact has given to United Kingdom significant know-how in the world, which is that cars from the Great Britain are high-quality and unique and that allows these companies push the prices high. [12][13][14]

\section{Conclusion}

We have compared in this article two countries, which are different in numerous aspects. It is power of the economy, history, mentality and culture, approach to the environment and tradition in manufacture. Goal of our index was to find out why has Great Britain in long term better rank than Slovak republic and what can Slovak republic do to change its rank. We have analysed data from all six dimensions and our conclusion is, that although Slovak republic is more peaceful country and can care less about our planet, next dimensions are putting it down. Some dimensions can be affected by country just really hard. Inscription in the UNESCO Heritage List can't be affected by higher investments or by promoting in the abroad, but tourism can be. Good Idea Slovakia is the tool how can Slovak republic become more interesting for tourists, but it can't be the only tool. Simple tool how to reach better score in Doing Business index can be in Slovak republic decreasing the bureaucracy, which is long term complication in the country, but it can't be the only tool. It needs also improve the infrastructure to get even more interesting for investors, although Slovak republic made significant changes that pulled forward direct investments in the country. And as the last one, Slovak republic needs to promote their production in abroad more. It is not enough for rest of the world to know, that in Slovak republic Volkswagen cars are made. If Slovak republic will start to promote their products, which are on the high-quality level, it can lift up the motivation for Slovak citizens to be creative too and eventually lift up level of living in the country. If it will succeed, in one dimension, it can pull up also other ones and with right directed investments for the support of these dimensions, it can change the position and name of the Slovakia in the Future Brand Index in the future. 
This contribution is the result of the project VEGA no. 1/0368/18 "Cenové stratégie v prostredí pôsobenia efektívnych regulačných mechanizmov na nadnárodných trhoch sietových odvetví slovenskej ekonomiky" in extent $50 \%$ and the project VEGA no. 1/0708/20 "Sociálno-ekonomické determinant trvalo udržatel'nej spotreby a výroby $\mathrm{z}$ hl'adiska vplyvu na výkonnost' a konkurencieschopnost' podnikov" in extent $50 \%$.

\section{References}

[1] FutureBrand, online at https://www.futurebrand.com/uploads/Country-Brand-Index-20 14-15.pdf (2015-2019)

[2] Global Footprint Network, online at http://data.footprintnetwork.org/\#/? (2019)

[3] European Commission, online at https://ec.europa.eu/commission/presscorner /detail/ en/IP_13_1035(2013)

[4] Vision of Humanity, online at http://visionofhumanity.org/indexes/global-peace-index/ (2019)

[5] The Institue for Econoics and Peace, Global Peace Index. online article at http://econ omicsandpeace.org/wp-content/uploads/2016/06/GPI-2016-Report_2.pdf (2016)

[6] D. Boffey, Slovakian journalist investigating claims of tax fraud linked to ruling party shot dead. online article at https://www.theguardian.com/world/2018/feb/26/slovakianjournalist-investigating-claims-of-tax-linked-to-ruling-party-shot-dead (2018)

[7] The world bank, online at https://www.doingbusiness.org/ (2020)

[8] Unesco. online at https://whc.unesco.org/en/about/ (2020)

[9] J. Jablonská, T. Pôbiš, G. M. Timčák, Beer tourism in Slovakia. Institute of Geotourism. FBERG, Technical University of Kosice (2018)

[10] K. Matlovicova, The Culinary Tourism in Slovak case study of the traditional local milk products in the regions of Orava and Liptov. GeoJournal of Tourism and Geosites, Oradea - Gdansk, 12, 3 (2013)

[11] Statista, online at https://www.statista.com/statistics/515696/inbound-tourism-mostvisited-uk-regions-united-kingdom/ (2018)

[12] Visit Britain. online at https://www.visitbritain.com/gb/en (2020)

[13] Apimed, online at https://www.apimed.sk/o-firme/ocenenia?lang=en (2020)

[14] Lyra, online at https://www.lyrachocolate.com/en (2020)

[15] Cheregi, Bianca-Florentina, Nation Branding in Transition Countries: A Multimodal Analysis of Romania and Moldova Tourism Campaigns. Journal of Entrepreneurship, Management and Innovation 14, 4, 81-106 (2018)

[16] A. S. Zemanek, Nation Branding in Contemporary Taiwan. A Grasroots Perspective. Culture, Theory and Critique 59, 2, 119138 (2018)

[17] G. Miazhevich, Nation branding in the post-broadcast era: The case of RT. European Journal of Cultural Studies 21, 5, 575-593 (2018)

[18] Y. Dubinsky, Analyzing the Roles of Country Image, Nation Branding, and Public Diplomacy through the Evolution of the Modern Olympic Movement. Physical Culture and Sport. Studies and Research 84.1: 27-40 (2019)

[19] H. L. Sataøen, Sub-sector branding and nation branding: the case of higher education. Corporate Communications: An International Journal (2019)

[20] L. Echeverri, E. ter Horst, G. Molina, Z. Mohamad, Nation Branding: Unveiling Factors that Affect the Image of Colombia from a Foreign Perspective, Tourism Planning \& Development (2017) 
[21] E. Vodopianova, L. Korobeynikova, Vestnik Tomskogo gosudarstvennogo universiteta. Kul'turologiya i iskusstvovedeniye. Tomsk State University Journal of Cultural Studies and Art History 35, 215-221 (2019)

[22] S. Fernández, J. Antonio, P. Azevedo, M. Jose, Determinants of tourism destination competitiveness in the countries most visited by international tourists: Proposal of a synthetic index. Tourism Management Perspectives (2019)

[23] M. Maričić, M.Bulajić, Z. Radojicic, V. Jeremic, Shedding Light on the Doing Business Index: a Machine Learning Approach. Business Systems Research Journal, 10, 73-84 (2019)

[24] L. Kilimova, Quality of life as a human development determinant in the context of economic instability. Economic Annals-XXI, 157, 59-61 (2016) 